\title{
Status Periodontal Anak Usia 8-12 Tahun di Sekolah Dasar Negeri 126 Manado
}

\author{
Amanda N. P. Mantiri \\ Vonny N. S. Wowor \\ Christy N. Mintjelungan
}

\author{
Program Studi Pendidikan Dokter Gigi Fakultas Kedokteran \\ Universitas Sam Ratulangi Manado \\ Email: amanda.mantiri@gmail.com
}

\begin{abstract}
Periodontal disease is a serious chronic infection that involves the destruction of tooth supporting tissues, including gum, periodontal ligaments, and alveolar bone. It is the second most common dental and oral disease suffered by people in the world after dental caries. According to $\mathrm{WHO}$, age 12 years has been chosen as an age group of global indicators for international comparison and surveillance of disease trends. This study was aimed to obtain the periodontal status of students 8-12 years old at SD Negeri 126 Manado (elementary school). This was a descriptive study with a cross sectional design. Respondents were 76 students obtained by using purposive sampling technique. Data of gum examination of all subjects were obtained by using WHO CPI probe and flat dental mirror and were analyzed univariately and presented in distribution tables. The results showed that 7 students $(9.2 \%)$ had healthy gums, meanwhile 69 students $(90.8 \%)$ had unhealthy gums, consisting of 66 students (86.8\%) with bleeding gums $\leq 50 \%$, and 3 students (4\%) with bleeding gums $\geq 51 \%$. Conclusion: Most students in this study had bleeding gum $\leq 50 \%$. Albeit, some students still had healthy gums.
\end{abstract}

Keywords: students aged 8-12 years, periodontal status, gingival bleeding

\begin{abstract}
Abstrak: Penyakit periodontal adalah infeksi kronis serius yang melibatkan penghancuran jaringan pendukung gigi, termasuk gingiva, ligamen periodontal, dan tulang alveolar. Penyakit ini tergolong penyakit gigi dan mulut kedua terbanyak yang diderita masyarakat di dunia setelah karies gigi. Menurut WHO, usia 12 tahun dipilih sebagai kelompok usia indikator global untuk perbandingan internasional dan surveilans kecenderungan penyakit. Penelitian ini bertujuan untuk mengetahui status periodontal siswa usia 8-12 tahun di SD Negeri 126 Manado. Jenis penelitian ialah deskriptif dengan desain potong lintang. Responden penelitian ialah 76 siswa, diambil dengan teknik purposive sampling. Data diperoleh berdasarkan pemeriksaan gingiva terhadap subyek menggunakan probe CPI WHO dan kaca mulut, kemudian diolah dengan cara analisis univariat serta disajikan dalam tabel distribusi frekuensi. Hasil penelitian menunjukkan bahwa 7 siswa $(9,2 \%)$ memiliki gingiva sehat, dan 69 siswa $(90,8 \%)$ yang tidak sehat terdiri dari 66 siswa $(86,8 \%)$ mengalami perdarahan gingiva $\leq 50 \%$, dan 3 siswa (4\%) mengalami perdarahan gingiva $\geq 51 \%$. Simpulan: Sebagian besar siswa usia 8-12 tahun di SD Negeri 126 Manado mengalami perdarahan gingival $\leq 50 \%$. Walaupun demikian, sebagian kecil siswa masih memiliki gingiva yang sehat.
\end{abstract}

Kata kunci: anak usia 8-12 tahun, status periodontal, perdarahan gingiva

Kesehatan gigi dan mulut merupakan bagian fundamental dari kesehatan secara umum serta berpengaruh terhadap kesejah- teraan. ${ }^{1}$ Rongga mulut dan gigi yang sehat menjadi hal yang sangat penting dan hanya dapat dicapai apabila rongga mulut sena- 
tiasa bersih. ${ }^{2}$ Menurut Soeroso et al. ${ }^{3}$ penyakit gigi dan mulut kedua terbanyak yang diderita masyarakat di dunia setelah karies gigi ialah penyakit periodontal. Penyakit periodontal juga dialami oleh hampir $90 \%$ masyarakat di Indonesia. $^{3}$ Penyakit periodontal adalah infeksi kronis serius yang melibatkan penghancuran jaringan pendukung gigi, termasuk gingiva, ligamen periodontal, dan tulang alveolar. Penyakit ini diprakarsai oleh akumulasi bakteri lokal yang berbatasan dengan gigi. ${ }^{4}$

Kebersihan gigi dan mulut merupakan faktor yang mendukung terciptanya kesehatan gigi dan mulut termasuk jaringan periodontal. Kebersihan gigi dan mulut yang kurang baik berisiko terhadap pembentukan kalkulus. ${ }^{5}$ Kalkulus timbul di daerah permukaan gigi yang sulit dibersihkan yang dapat menyebabkan masalah pada jaringan periodontal seperti gingivitis, periodontitis bahkan jika berlangsung lebih lama akan menyebabkan kehilangan gigi. ${ }^{6}$ Kondisi gigi seperti ini merupakan salah satu penyakit peradangan kronik yang paling umum, yang memengaruhi sebagian besar populasi di seluruh dunia. ${ }^{4}$ Data Riskesdas 2013 menunjukkan prevalensi penduduk yang bermasalah dengan gigi dan mulut di Sulawesi Utara sebesar 31,6\%. ${ }^{7}$

Menurut $\mathrm{WHO},{ }^{8}$ usia 12 tahun sangat penting karena umumnya pada usia tersebut anak-anak telah meninggalkan sekolah dasar. Oleh karena itu di banyak negara, usia ini merupakan usia terakhir dimana sampel penelitian yang dapat diandalkan dapat diperoleh dengan mudah melalui sistem sekolah. Selain itu kemungkinan bahwa pada usia ini semua gigi tetap telah erupsi kecuali molar ketiga. Untuk alasan ini, usia 12 tahun telah dipilih sebagai kelompok usia indikator global untuk perbandingan internasional dan surveilans kecenderungan penyakit.

Tjahyad dan Andini pada tahun 2011 menyatakan masalah kesehatan gigi dan mulut merupakan masalah yang rentan dihadapi oleh kelompok anak usia Sekolah Dasar (SD). Masalah gigi pada anak usia sekolah timbul karena perawatan gigi yang buruk. Salah satu masalah gigi yang diala- mi anak sekolah ialah penyakit periodontal. Penyebab dari permasalahan gigi tersebut antara lain ukuran gigi yang lebih besar dari ukuran rahang, jenis makanan yang dikonsumsi anak lebih banyak yang bersifat lunak/lembut, manis dan lengket, lamanya sisa makanan tertinggal dalam mulut yang tidak cepat dibersihkan, kurangnya menjaga kebersihan mulut dan gigi yang tidak tepat, dan penggunaan pasta gigi yang belum tepat. ${ }^{9}$ Menurut Wong et al., pada usia 6-12 tahun sekolah menjadi pengalaman inti anak. Cara memelihara kesehatan gigi dan mulut secara lebih rinci dapat diajarkan pada anak, sehingga akan menimbulkan rasa tanggung jawab akan kebersihan diri sendiri. ${ }^{10}$ Hasil penelitian yang dilakukan oleh Ade tahun 2014 menunjukkan presentase penderita gingivitis pada anak usia 8-12 tahun mencapai 43,6\%. ${ }^{11}$

Penelitian ini dilakukan pada siswa SD Negeri 126 Manado yang pada survei awal diketahui merupakan salah satu sekolah favorit di Kecamatan Malalayang dengan karakteristik siswa beragam. Di sekolah ini belum pernah dilakukan penelitian tentang status periodontal khususnya perdarahan gingival. Penelitian ini bertujuan untuk mendapatkan status periodontal anak usia 8-12 tahun di SD Negeri 126 Manado.

\section{METODE PENELITIAN}

Penelitian ini merupakan penelitian deskriptif dengan desain potong lintang untuk mendapatkan status periodontal pada anak di SD Negeri 126 Manado. Penelitian dilaksanakan pada bulan Agustus 2018 di SD Negeri 126 Manado, Kecamatan Malalayang, Kota Manado, Provinsi Sulawesi Utara. Populasi penelitian ini yaitu seluruh anak SD Negeri 126 Manado berusia 8-12 tahun yang berdasarkan survei awal berjumlah 93 siswa. Jumlah responden penelitian diperoleh dengan menggunakan rumus Slovin yaitu sebesar 76 siswa. Untuk menentukan jumlah responden yang mewakili masing-masing kelas dimana responden penelitian berada digunakan metode proportional random sampling dengan menggunakan rumusan alokasi proporsional sebagai berikut: kelas 2 sebanyak 9 
siswa; kelas 3 sebanyak 17 siswa, kelas 4 sebanyak 16 siswa, kelas 5 sebanyak 18 siswa, dan kelas 6 sebanyak 16 siswa

Teknik pengambilan sampel yang digunakan ialah teknik purposive sampling. Pengambilan responden penelitian yaitu siswa yang lebih dulu istirahat dan datang di ruangan pemeriksaan serta mendapatkan izin melalui informed concent dan sesuai dengan kriteria inklusi serta eksklusi sampai jumlah respodnen penelitian terpenuhi berdasarkan kuota perkelasnya.

Kalkulasi penilaian perdarahan gingiva (gingival bleeding) ialah sebagai berikut:

Perdarahan gingiva $=$

Jumlah perdarahan

$\begin{array}{ll}\text { Jumlah sisi yang diperiksa } & \times 100 \%\end{array}$

Hasil penilaian gingiva dibagi menjadi 2 (dua) kategori yaitu sehat dan tidak sehat (gingiva dengan perdarahan). Yang tidak sehat terdiri dari perdarahan gingiva $\leq 50 \%$, dan perdarahan gingiva $\geq 51 \%$.

Alat dan bahan yang digunakan dalam penelitian ialah formulir pemeriksaan status periodontal, alat tulis menulis, probe Community periodontal index (CPI) WHO, kaca mulut, pinset, piala ginjal, sarung tangan, masker, ember, kamera, kapas, tisu, povidone iodine, alkohol $70 \%$, Germisep atau Byclin, dan air minum kemasan untuk berkumur.

Persiapan penelitian yaitu mengumpulkan kembali lembar penjelasan penelitian, lembar informed concent, dan formulir pemeriksaan (data subyek) yang diberikan sebelumnya dan telah mendapat tanda tangan persetujuan dari orang tua siswa,

Langkah pemeriksaan yaitu pemeriksaan gingiva (instruksikan kepada subyek agar duduk rileks dan tegak, instruksikan agar membuka mulut, masukkan kaca mulut, masukkan probe ke dalam sulkus gigi dan mengelilingi sulkus dengan kekuatan tekan tidak lebih dari 20 gram, untuk sisi labial/bukal jalankan probe searah mulai dari mesial ke distal, untuk sisi palatal/lingual jalankan probe searah mulai dari mesial ke distal), kemudian pencatatan skor-skor pemeriksaan gingiva pada formulir pemeriksaan, verifikasi kembali skor keadaan gingiva dengan skor yang tercatat pada formulir pemeriksaan, dan sterilisasi/desinfeksi alat.

Analisis data dilakukan secara univariat untuk mendeskripsikan data secara sederhana. Data disajikan dalam bentuk tabel distribusi frekuensi.

\section{HASIL PENELITIAN}

Responden penelitian ialah 76 siswa SD Negeri 126 Manado berusia 8-12 tahun dari populasi 93 siswa. Karakteristik responden penelitian dibagi berdasarkan distribusi jenis kelamin dan usia (Tabel 1 dan 2). Tabel 1 menunjukkan bahwa karakteristik responden penelitian berdasarkan jenis kelamin terdiri dari $42(55,3 \%)$ lakilaki dan $34(44,7 \%)$ perempuan.

Tabel 1. Distribusi responden penelitian berdasarkan jenis kelamin

\begin{tabular}{ccc}
\hline $\begin{array}{c}\text { Jenis } \\
\text { kelamin }\end{array}$ & $\begin{array}{c}\text { Jumlah } \\
(\mathbf{n})\end{array}$ & $\begin{array}{c}\text { Persentase } \\
(\boldsymbol{\%})\end{array}$ \\
\hline Laki-laki & 42 & 55,3 \\
Perempuan & 34 & 44,7 \\
Total & 76 & 100,0 \\
\hline
\end{tabular}

Tabel 2 menunjukkan bahwa karakteristik responden penelitian berdasarkan usia terdiri dari 10 siswa $(13,2 \%)$ berusia 8 tahun, 14 siswa $(18,4 \%)$ berusia 9 tahun, 11 siswa $(14,5 \%)$ berusia 10 tahun, 23 siswa $(30,2 \%)$ berusia 11 tahun, dan 18 siswa $(23,7 \%)$ berusia 12 tahun.

Tabel 2. Distribusi responden penelitian berdasarkan usia

\begin{tabular}{ccc}
\hline $\begin{array}{c}\text { Usia } \\
\text { (tahun) }\end{array}$ & $\begin{array}{c}\text { Jumlah } \\
(\mathbf{n})\end{array}$ & $\begin{array}{c}\text { Persentase } \\
(\%)\end{array}$ \\
\hline 8 & 10 & 13,2 \\
9 & 14 & 18,4 \\
10 & 11 & 14,5 \\
11 & 23 & 30,2 \\
12 & 18 & 23,7 \\
Total & 76 & 100,0 \\
\hline
\end{tabular}


Distribusi status periodontal pelajar SD Negeri 126 Manado usia 8-12 tahun berdasarkan pengukuran bleeding on probing (Lenox dan Kopczy) disajikan dalam Tabel 3 dan Tabel 4. Tabel 3 menunjukkan bahwa 7 siswa $(9,2 \%)$ memiliki gingiva sehat dan 69 siswa $(90,8 \%)$ memiliki gingiva tidak sehat. Yang memiliki gingiva tidak sehat terdiri dari 66 siswa $(86,8 \%)$ dengan perdarahan gingiva $\leq 50 \%$, dan 3 siswa (4\%) dengan perdarahan gingiva $\geq 51 \%$.

Tabel 3. Distribusi status periodontal responden berdasarkan pemeriksaan kondisi gingiva dengan pengukuran bleeding on probing

\begin{tabular}{ccc}
\hline Kondisi gingiva & $\begin{array}{c}\text { Jumlah } \\
(\mathbf{n})\end{array}$ & $\begin{array}{c}\text { Persentase } \\
(\boldsymbol{\%})\end{array}$ \\
\hline Sehat & 7 & 9,2 \\
Tidak Sehat: & 69 & 90,8 \\
(Perdarahan & $(66)$ & $(86,8)$ \\
gingiva $\leq 50 \%)$ & & \\
(Perdarahan & $(3)$ & $(4,0)$ \\
gingiva $\geq 51 \%)$ & 76 & 100,0 \\
Total & 76 \\
\hline
\end{tabular}

Tabel 4 menunjukkan bahwa hasil pemeriksaan pada responden laki-laki mendapatkan 3 siswa (4\%) memiliki gingiva sehat dan 39 siswa $(51,2 \%)$ memiliki gingiva tidak sehat. Yang memiliki gingiva tidak sehat terdiri dari 37 siswa $(48,6 \%)$ dengan perdarahan gingiva $\leq 50 \%$, dan 2 siswa $(2,6 \%)$ dengan perdarahan gingiva $\geq 51 \%$. Tabel 5 menunjukkan bahwa hasil pemeriksaan pada responden perempuan mendapatkan 4 siswa $(5,3 \%)$ memiliki gingiva sehat dan 30 siswa $(39,5 \%)$ memiliki gingiva tidak sehat. Yang memiliki gingiva tidak sehat terdiri dari 29 siswa $(38,2 \%)$ dengan perdarahan gingiva $\leq 50 \%$, dan 1 siswa $(1,3 \%)$ dengan perdarahan gingiva $\geq 51 \%$.

Distribusi latar belakang yang memengaruhi perilaku anak yaitu berdasarkan pekerjaan orangtua, pendidikan terakhir orang tua, dan frekuensi anak menyikat gigi dalam sehari disajikan dalam Tabel 5, Tabel 6, dan Tabel 7.

Tabel 4. Distribusi status periodontal anak berdasarkan jenis kelamin

\begin{tabular}{llccc}
\hline \multicolumn{1}{c}{ Kondisi gingiva } & \multicolumn{4}{c}{ Jenis kelamin } \\
\cline { 2 - 5 } & \multicolumn{2}{c}{ Laki-laki } & \multicolumn{3}{c}{ Perempuan } \\
& $\mathrm{n}$ & $\%$ & $\mathrm{n}$ & $\%$ \\
\hline Sehat & 3 & 4 & 4 & 5,3 \\
Tidak sehat: & 39 & 51,2 & 30 & 39,5 \\
(Perdarahan gingiva $\leq 50 \%)$ & $(37)$ & $(48,6)$ & $(29)$ & $(38,2)$ \\
(Perdarahan gingiva $\geq 51 \%)$ & $(2)$ & $(2,6)$ & $(1)$ & $(1,3)$ \\
\multicolumn{1}{c}{ Total } & 42 & 55,2 & 34 & 44,8 \\
\hline
\end{tabular}

Tabel 5 menunjukkan bahwa terdapat 49 orang tua $(64,47 \%)$ yang bekerja sebagai PNS, dan terdapat 27 orang tua $(35,53 \%)$ yang bekerja sebagai non-PNS.

Tabel 5. Distribusi responden penelitian berdasarkan pekerjaan orang tua

\begin{tabular}{ccc}
\hline $\begin{array}{c}\text { Pekerjaan } \\
\text { orang tua }\end{array}$ & $\begin{array}{c}\text { Jumlah } \\
(\mathbf{n})\end{array}$ & $\begin{array}{c}\text { Persentase } \\
(\mathbf{\%})\end{array}$ \\
\hline PNS & 49 & 64,47 \\
Non-PNS & 27 & 35,53 \\
Total & 76 & 100,0 \\
\hline
\end{tabular}

Tabel 6 menunjukkan bahwa 24 orang tua $(31,58 \%)$ memiliki pendidikan terakhir SMA/sederajat, dan 52 orang tua $(68,42 \%)$ memiliki pendidikan terakhir $\geq \mathrm{S}$.

Tabel 6. Distribusi berdasarkan pendidikan terakhir orang tua

\begin{tabular}{ccc}
\hline $\begin{array}{c}\text { Pendidikan } \\
\text { terakhir orang tua }\end{array}$ & $\begin{array}{c}\text { Jumlah } \\
(\mathbf{n})\end{array}$ & $\begin{array}{c}\text { Persentase } \\
(\mathbf{\%})\end{array}$ \\
\hline SMA/sederajat & 24 & 31,58 \\
$\geq$ S1 & 52 & 68,42 \\
Total & 76 & 100,0 \\
\hline
\end{tabular}


Tabel 7 menunjukkan bahwa terdapat 42 siswa $(55,26 \%)$ yang memiliki frekuensi menyikat gigi $\leq 1$ kali dalam sehari, dan terdapat 34 siswa $(44,74 \%)$ yang memiliki frekuensi menyikat gigi $\geq 2$ kali dalam sehari.

Tabel 7. Distribusi frekuensi anak menyikat gigi dalam sehari

\begin{tabular}{ccc}
\hline $\begin{array}{c}\text { Frekuensi } \\
\text { menyikat gigi } \\
\text { dalam sehari }\end{array}$ & $\begin{array}{c}\text { Jumlah } \\
(\mathbf{n})\end{array}$ & $\begin{array}{c}\text { Persentase } \\
(\boldsymbol{\%})\end{array}$ \\
\hline$\leq 1$ kali & 42 & 55,26 \\
$\geq 2$ kali & 34 & 44,74 \\
Total & 76 & 100,0 \\
\hline
\end{tabular}

\section{BAHASAN}

Responden penelitian ini yaitu siswa SD Negeri 126 Manado yang berusia 8-12 tahun. Penetapan usia yang digunakan dihitung berdasarkan terakhir kali responden berulang tahun. ${ }^{12}$ Jumlah responden pada penelitian ini sebanyak 76 siswa dari populasi sebanyak 93 siswa, terdiri dari 42 laki-laki dan 34 perempuan.

Hasil penelitian menunjukkan bahwa terdapat sebagian kecil yang memiliki gingiva sehat yaitu 7 siswa $(9,2 \%)$. Kondisi gingiva sehat ini dapat terjadi karena kebiasaan yang baik dalam menjaga kesehatan gigi dan mulut yang dilakukan oleh siswa tersebut. Hasil penelitian ini sejalan dengan penelitian yang dilakukan oleh Karim et al. ${ }^{12}$ pada siswa di salah satu sekolah dasar yang menunjukkan bahwa gingiva sehat terdapat pada 4 orang $(8,51 \%)$ subjek penelitian. Hasil penelitian ini menunjukkan bahwa masih rendahnya jumlah responden penelitian yang memiliki status periodontal sehat. Hal ini menunjukkan masih jauhnya hasil penelitian ini dari target yang ditetapkan oleh WHO pada tahun 2010 yaitu usia 12 tahun merupakan important age group. ${ }^{8}$

Hasil penelitian ini juga menunjukkan bahwa siswa yang memiliki gingiva tidak sehat sebanyak 69 anak $(90,8 \%)$. Siswa dengan gingiva tidak sehat terdiri dari yang mengalami perdarahan gingiva $\leq 50 \%$ sebanyak 66 anak (86,8\%), dan yang mengalami perdarahan gingiva $\geq 51 \%$ sebanyak 17 anak (9\%). Pada penelitian ini masalah gingiva paling banyak ditemukan pada siswa yang berusia 11 tahun yaitu 23 anak $(30,2 \%)$. Kondisi gingiva tidak sehat ini dapat terjadi karena kebiasaan yang kurang baik dalam menjaga kesehatan gigi dan mulut oleh siswa tersebut.

Hasil penelitian ini sejalan dengan penelitian yang dilakukan oleh Karim et al. ${ }^{12}$ yang menyatakan bahwa masalah gingiva paling banyak ditemui pada siswa yang berusia 11 tahun yaitu 17 orang $(36,17 \%)$ dan juga sejalan dengan penelitian yang dilakukan oleh Hafsari ${ }^{13}$ yang menyatakan bahwa prevalensi tertinggi yaitu $90 \%$ pada anak dengan usia 11 tahun.

Hasil penelitian menunjukkan bahwa paling banyak siswa berusia 8-12 tahun mengalami perdarahan gingival. Hal ini bisa dipengaruhi oleh beberapa faktor yang dapat menyebabkan penyakit periodontal yaitu karena adanya faktor primer berupa iritasi bakteri dan faktor sekunder berupa faktor lokal dan sistemik. Faktor lokal dapat berupa restorasi yang keliru, kavitas karies, tumpukan sisa makanan, geligi tiruan yang desainnya tidak baik, alat ortodonti, susunan gigi-geligi yang tidak teratur, kurangnya seal bibir atau kebiasaan bernafas melalui mulut, dan merokok. Faktor sistemik dapat berupa faktor genetik, nutrisi, hormonal, dan hematologi (penyakit darah). ${ }^{14}$ Pada siswa berusia 1112 tahun faktor sistemik yang dapat memengaruhi kondisi jaringan periodontal ialah faktor hormonal. Perubahan yang berlangsung pada masa pubertas dapat menimbulkan perubahan jaringan gingiva yang mengubah respon terhadap bakteri atau produk-produk plak. Perubahan hormonal pada masa pubertas dapat menyebabkan inflamasi yang hebat yang diikuti dengan pembengkakan dan perdarahan gingiva. ${ }^{15}$

Hasil penelitian menunjukkan bahwa paling banyak ditemukan pada subjek penelitian laki-laki yaitu perdarahan gingiva $\leq 50 \%$ sebanyak 37 siswa $(46,6 \%)$, dan perdarahan $\geq 51 \%$ sebanyak 2 siswa $(2,6 \%)$. Hal ini selaras dengan penelitian yang dilakukan oleh Karim et al. ${ }^{12}$ yang menya- 
takan bahwa perdarahan gingiva lebih banyak ditemukan pada jenis kelamin lakilaki yaitu sebanyak 25 orang $(53,19 \%)$.

Hasil penelitian ini juga menunjukkan bahwa jumlah responden penelitian perempuan yang memiliki status gingiva sehat lebih banyak daripada responden penelitian laki-laki. Hasil penelitian ini sesuai dengan penelitian yang dilakukan di Udaipur India yang menunjukkan bahwa subjek penelitian perempuan memiliki status gingiva sehat lebih banyak daripada subjek penelitian laki-laki. ${ }^{16}$ Alasan mengapa jenis kelamin bisa memengaruhi status periodontal bisa dikaitkan dengan kebiasaan dan kecenderungan perempuan yang dapat menjaga kebersihan rongga mulutnya lebih baik daripada laki-laki. ${ }^{17}$

Kondisi gingiva sehat dapat terjadi karena kebiasaan yang baik dalam menjaga kesehatan gigi dan mulut yang dilakukan oleh anak tersebut contohnya frekuensi anak dalam menyikat gigi dalam sehari. Berdasarkan penelitian ini didapatkan yang menyikat giginya $\geq 2$ kali sehari sebanyak 34 siswa $(44,74 \%)$ dan yang menyikat giginya $\leq 1$ kali dalam sehari sebanyak 42 siswa $(55,26 \%)$. Bila dikaitkan dengan hasil penelitian yaitu banyak siswa yang memiliki gingiva tidak sehat, penulis berasumsi bahwa frekuensi anak menyikat gigi berpengaruh terhadap kebersihan gigi dan mulutnya, yang tentunya bila kebersihan gigi dan mulut terjaga akan berdampak dengan sehatnya gingiva. Begitu juga sebaliknya bila kebersihan gigi dan mulutnya kurang baik akan berdampak dengan keadaan gingiva yang tidak sehat. Hal ini sejalan dengan penelitian yang dilakukan oleh Pintauli ${ }^{17}$ di salah satu sekolah dasar di Medan yang melaporkan bahwa terdapat hubungan bermakna antara perilaku pemeliharaan kesehatan gigi dan mulut terhadap kesehatan gigi dan mulut.

Hasil penelitian ini menunjukkan bahwa terdapat 49 orang tua $(64,47 \%)$ yang bekerja sebagai PNS dan 27 orang tua $(35,53 \%)$ yang bekerja sebagai non PNS (pegawai swasta, wirausaha, dan buruh). Bila dikaitkan dengan hasil penelitian banyak anak yang memiliki gingiva tidak sehat, penulis berasumsi bahwa latar belakang perilaku anak dipengaruhi keluarga khususnya orang tua. Pekerjaan orang tua kebanyakan PNS dan kesibukan orang tua diduga dapat mengakibatkan kurangnya waktu orangtua untuk memonitor anaknya misalnya frekuensi menyikat gigi atau jajanan yang dikonsumsi di sekolah. Berbeda halnya pada pekerjaan orang tua yang non-PNS kemungkinan orang tua mempunyai waktu lebih untuk bersama anak dan mengawasi jajanan yang dikonsumsi anak di sekolah sehingga kebersihan gigi dan mulut anak cenderung baik.

Hasil penelitian ini menunjukkan bahwa terdapat 24 orang tua $(31,58 \%)$ yang memiliki pendidikan terakhir SMA/sederajat dan 52 orang tua $(68,42 \%)$ yang memiliki pendidikan terakhir S1 dan di atas S1. Bila dikaitkan dengan hasil penelitian banyak siswa yang memiliki gingiva tidak sehat, penulis berasumsi bahwa latar belakang perilaku anak tidak dipengaruhi oleh pendidikan terakhir orang tua, karena walaupun banyak orang tua yang berpendidikan tinggi namun tidak berdampak baik bagi kesehatan gigi dan mulut anaknya.

\section{SIMPULAN}

Berdasarkan hasil penelitian inin dapat disimpulkan bahwa sebagian besar siswa berusia 8-12 tahun di SD Negeri 126 mengalami perdarahan gingiva $\leq 50 \%$. Walaupun demikian, sebagian kecil siswa masih memiliki gingiva yang sehat.

\section{SARAN}

Bagi pihak pemerintah dalam hal ini pihak Puskesmas Kecamatan Malalayang, dapat memanfaatkan hasil penelitian ini untuk merancang program upaya promotifpreventif di tingkat Sekolah Dasar guna meningkatkan status kesehatan gigi mulut masyarakat terlebih khusus anak sekolah dasar.

Bagi siswa sekolah dasar yang menjadi sasaran upaya promotif-preventif kesehatan gigi dan mulut, diharapkan dapat memanfaatkan pengetahuan yang diperoleh untuk merubah perilaku pemeliharaan kesehatan gigi dan mulut ke arah yang baik dan benar. 
Bagi institusi diharapkan dapat memperkaya referensi kepustakaan yang ada di institusi untuk dapat dimanfaatkan oleh mahasiswa dan tenaga pengajar serta dapat menjadi dasar bagi penelitian selanjutnya.

\section{DAFTAR PUSTAKA}

1. World Health Organization. Continuous improvement of oral health in $21^{\text {st }}$ century: the approach of the WHO global oral health programme, the World Oral Health report. Geneva: WHO, 2003; p. 3. [cited 2018 Feb 22]. Available from: http://www.who.int/ oral_health/media/en/orh_report03_en. pdf.

2. Bangash RY, Khan AU, Tariq KM, Rasheed D. Evaluation of tooth brushing technique and oral hygiene knowledge at Afid, Rawalpindi. Pakistan Oral \& Dental Journal. 2012;32(1):124-7.

3. Soeroso Y, Octavia M, Salim R, Setiawan J. Perkembangan terapi periodontal non bedah pada periodontitis kronis. Jakarta: The third national scientific seminar in periodontics - IPERI, 2014; p. 11-7

4. Genco R J, Williams RC. Periodontal disease and overall health: a clinician'sguide. Yardley, Pennsylvania: Professional audience communications, Inc, 2010.

5. Pintauli S, Hamada T. Menuju gigi dan mulut sehat, pencegahan dan pemeliharaan. Medan: USU Press, 2008; p. 4-18.

6. Petersen PE. The world oral health report 2003. [cited 2018 Feb 22]. Available from:http://www.who.int/entity/oral_ health/media/en/orh_reports03_en.pdf

7. Riset Kesehatan Dasar 2013. Laporan nasional Departemen Kesehatan Republik Indonesia. [cited 2018 Feb 22]. Available from: www.depkes.go.id/ resources/download/general/Hasil\%20 Riskesdas\%202013.pdf

8. World Health Organization. Oral Health
Surveys-Basic Methods (5 th ed), 2013; p. 35. [cited 2018 Feb 23]. Available from: https://www.who.int/oral_health/ publications/9789241548649/en/

9. Tevatia S. Puberty induced gingival enlargement. Biomed J Sci \& Tech Res. 2017. DOI: 10.26717/BJSTR.2017.01.00126.

10. Slat ME, Suling PL, Zuliari K. Gambaran status jaringan periodontal pada pelajar di SMA Negeri 1 Manado. 2013. p. 5-6

11. Hanapi AN. Angka kejadian karies dan gingivitis pada anak sekolah dasar usia 8-12 tahun di kabupaten Maros tahun 2014 [Skripsi]. Makassar: Fakultas Kedokteran Gigi Universitas Hasanuddin; 2014.

12. Karim CAA, Gunawan P, Wicaksono DA. Gambaran status gingiva pada anak usia sekolah dasar di SD GMIM Tonsea Lama. Manado. eG. 2013;1(2).

13. Hafsari LS. Perawatan dasar gingivitis pada anak [Skripsi]. Medan: Fakultas Kedokteran Gigi Universitas Sumatera Utara; 2003.

14. Gani A, Taufiqurrahman. Kebutuhan perawatan periodontal pada remaja di Kabupaten Sinjai tahun 2007. Dentofasial. 2008;7(2):132-8.

15. Nagarajappa R, Kenchappa M, Ramesh G, Nagarajappa S, Tak M. Assesment of periodontal status and treatment needs among 12 and 15 years old school children in Udiapur, India. European Achieves of Pediatric Dentistry. 2012;13(3):132-7.

16. Sanei AS, Nikbakht-Nasrabadi A. Periodontal health status and treatment needs in Iranian adolescent population. Arch Iranian Med. 2005;8(4):290-4.

17. Pintauli S. Analisis hubungan perilaku pemeliharaan kesehatan gigi dan mulut terhadap status kesehatan gigi dan mulut siswa SD dan SMP di Medan. Jurnal Pendidikan dan Kebudayaan. 2010;10(4):376-90. 